\title{
A retrospective view of noise pollution control policy in India: status, proposed revisions and control measures
}

\author{
N. Garg* and S. Maji
}

This article provides a retrospective view of noise policies and ordinances in India. It also proposes revisions in them for noise abatement and control based on the available knowledge on noise policies and regulations followed around the world. The work focuses on the inclusion of noise limits for construction activities, household appliances apart from the revision in ambient noise standards and National Building Codes for protection against noise pollution. It is envisaged that the proposed revisions and work plan shall be instrumental in execution of noise abatement action plans for controlling noise pollution in India.

Keywords: Ambient noise standards, control measures, noise pollution, polices and ordinances.

NOISE pollution has become a serious problem for the society. In India, with expanding vehicular population traffic noise levels have increased, which can cause serious health effects. The World Health Organization (WHO) recognized noise as one of the major pollutants affecting the health of the human population ${ }^{1}$. The major sources of noise pollution are: road traffic, rail, aircraft noise, construction noise, noise emitted from the industrial set-ups, honking noise from vehicles, noise emitted from household appliances, loudspeakers, community processions, etc. Road traffic noise has been observed to be the major source of noise pollution in most of these studies carried out in different parts of the world ${ }^{2-4}$. Long-term noise monitoring studies are required not only for ascertaining the magnitude of ambient levels, but also for devising suitable control action plans. The European Environmental Noise Directive 2002/49/EC relating to the assessment and management of environmental noise establishes that the member states should create noise maps for the parts of their territory in terms of singlenoise descriptors: day-evening-night level $\left(L_{\mathrm{den}}\right)$ and night equivalent level $\left(L_{\text {night }}\right)$ respectively ${ }^{5}$. Implementing long-term and short-term noise monitoring strategies for measuring the ambient noise levels in various part of cities and planning of suitable abatement measures for reducing noise pollution in Indian cities are essential. The Central Pollution Control Board (CPCB), New Delhi, has initiated a National Ambient Noise Monitoring Network

\footnotetext{
N. Garg is in the CSIR-National Physical Laboratory, New Delh 110012 , India; S. Maji is in the Delhi Technological University, Delhi 110042 , India.

*For correspondence. (e-mail: ngarg@nplindia.org)
}

(NANMN) with an objective of collecting real-time noise monitoring data from major cities of India ${ }^{6-8}$. The network provides ambient noise level data which can be helpful in identification of noisy spots and adoption of suitable measures of abatement for noise pollution control. A retrospective view of the ambient noise standards and National Building Codes of India is required so as to ensure that the current standards, noise policies and legislations are suitable and effective enough to control noise pollution in India. The development of a validated road traffic noise model ${ }^{9,10}$ integrated with a GIS interface for developing noise maps for Indian cities shall be indispensable in conducting Environmental Impact Assessment (EIA) studies especially for new projects and development of 'smart cities' concept implemented recently by the Government of India (GoI).

The objective of the present work is to study the status of policies and ordinances in the Indian scenario, and propose revisions for noise abatement and control based on the available knowledge on noise policies and regulations around the world ${ }^{11}$. This independent study is based on the available knowledge on noise policies and regulations followed around the world. It has nothing to do with any legal or Government body sponsoring the work, or accepting the conclusions of the present work. As such, in India, it is the prerogative of many Government agencies including CPCB, State Pollution Control Boards, Ministry of Environment and Forests (MoEF), GoI in consultation with National Committee on Noise Pollution Control to formulate and revise the ambient noise standards, ordinances and legislations. The Panel for Acoustics, Sound Insulation and Noise Control, CED $46:$ P20, constituted by the Bureau of Indian Standards 


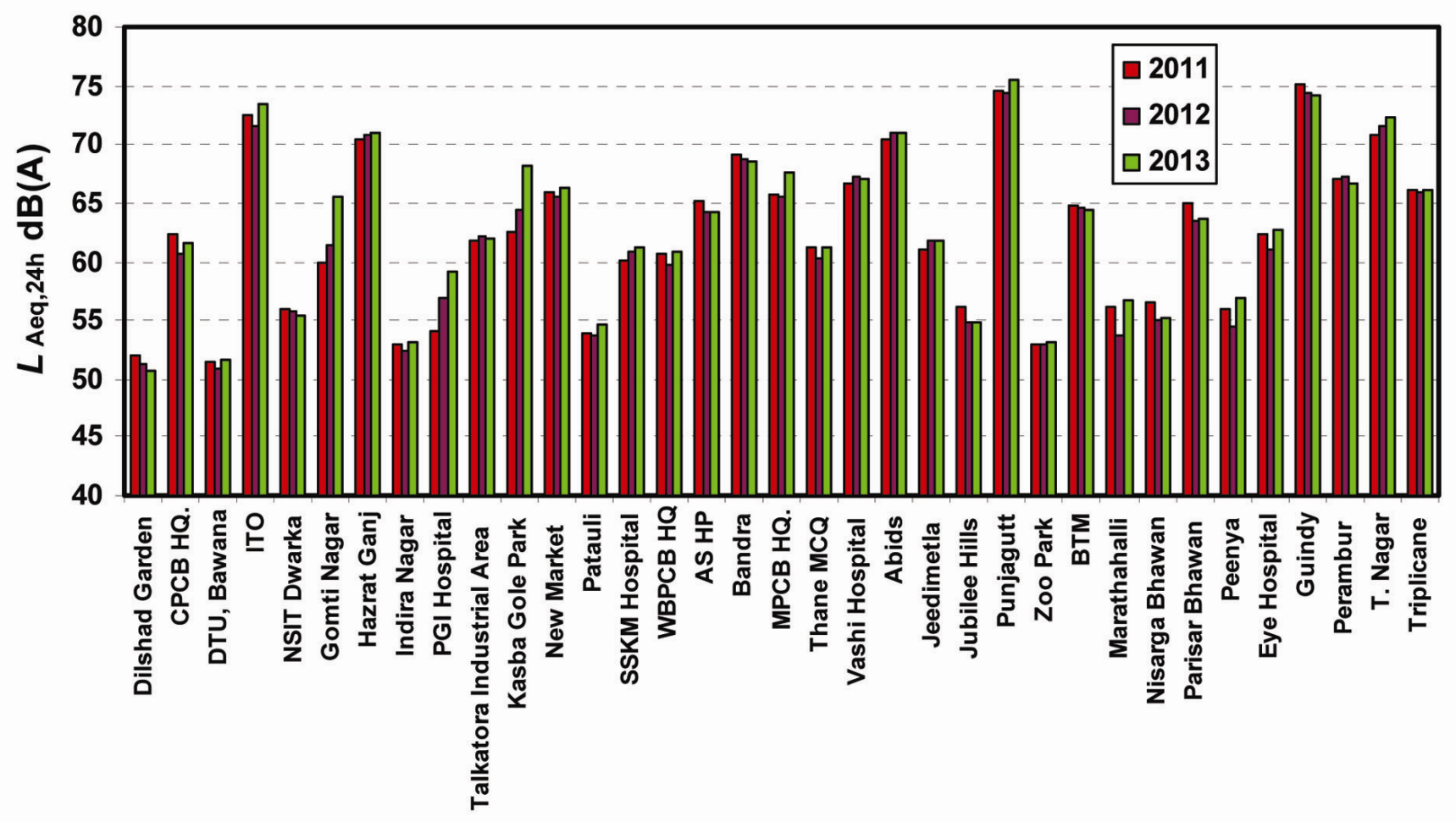

Figure 1. $L_{\text {Aeq, } 24 \mathrm{~h}}$ at 35 locations spread across seven major cities all over India during 2011-2013.

is responsible for amendments and revisions in National Building Codes of India ${ }^{12}$. Although the proposed revisions in the ambient noise standards and sound regulation requirements have been explicitly discussed earlier ${ }^{13,14}$, the objective of the present study is to consider the overall noise pollution control policies, ordinances and measures for all types of noise sources in totality in the Indian scenario and suggesting a road map for developing a 'noise-free community' in Indian cities in the next decades.

\section{NANMN project: status and implications}

The NANMN project was established in 2011 by CPCB. Phase I of NANMN covers 35 locations in seven metro cities of India. Among these, 14 locations lie in commercial zones, 5 in industrial, 7 in residential and 9 in silence zones. The details of the project and analysis of available noise data have been discussed elaborately in the literature ${ }^{8,15-17}$. Figure 1 shows the equivalent continuous sound pressure level for $24 \mathrm{~h}$ duration, $L_{\text {Aeq,24h }}$ levels at 35 locations spread across seven major cities all over India during 2011-2013. It can be observed from the 2013 noise monitoring data that 11 out of the 35 sites $(31.4 \%)$

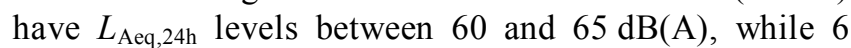
sites $(17.1 \%)$ have ambient noise levels more than $70 \mathrm{~dB}(\mathrm{~A})$. Eleven sites have ambient noise levels less than $60 \mathrm{~dB}(\mathrm{~A}) L_{\mathrm{Aeq}, 24 \mathrm{~h} .} L_{\mathrm{Aeq}, 24 \mathrm{~h}}$ levels varied from 50.8 to $67.1 \mathrm{~dB}(\mathrm{~A})$ in 2013 for the silence zones, while for residential areas, they varied from 53.1 to $66.1 \mathrm{~dB}(\mathrm{~A})$. For commercial zones, the $L_{\text {Aeq,24h }}$ levels varied from 56.7 to $75.4 \mathrm{~dB}(\mathrm{~A})$, while for industrial zones, they varied from 57.0 to $74.2 \mathrm{~dB}(\mathrm{~A})$. The Punjagutta commercial area had maximum $L_{\mathrm{Aeq}, 24 \mathrm{~h}}$ level of $75.4 \mathrm{~dB}(\mathrm{~A})$, while the Dilshad Garden had minimum $L_{\text {Aeq,24h }}$ level of $50.8 \mathrm{~dB}(\mathrm{~A})$. Analysis of data also reveals that $L_{\mathrm{Aeq}, 24 \mathrm{~h}}$ levels have marginally increased in three years, except for the sites Gomti Nagar, PGI Hospital and Kasba Gole Park, where an increase in ambient levels of $\geq 5 \mathrm{~dB}(\mathrm{~A})$ is noticed. Thus, the noise monitoring data acquired from these sites are instrumental in analysing the scenario in seven cities of India and adopting suitable noise pollution control measures. The numbers of monitoring stations has increased to 70 in 2014, with each city having ten noise monitoring stations.

\section{Proposed revisions in the ambient standards and National Building Codes}

With expanding vehicular population, especially in metro cities, it is necessary to amend the ambient noise standards to reasonable values that can be easily enforced, so as to control the noise pollution levels. Table 1 shows the proposed ambient noise standards ${ }^{13}$. The modified adjustments to ISO 1996-1:2003 (ref. 18) recommendations 
are to be added to the measured or predicted $L_{\mathrm{Aeq}, 24 \mathrm{~h}}$ depending upon the type of sound source and the character of sound as explicitly mentioned in Garg et al. ${ }^{13}$. The detailed explanation and basis for selecting a cumulative noise exposure metrics such as $L_{\text {Aeq,24h }}$ and modified adjustments proposed can be found in Garg et al. ${ }^{13}$. It is proposed that for areas under silence zone, the limit is $55 \mathrm{~dB}(\mathrm{~A})$; while for commercial area, and mixed residential and commercial zones, the limit is recommended as $65 \mathrm{~dB} L_{\text {Aeq,24h. }}$. The underlying objective behind adding the modified adjustments to ISO 1996-1:2003 to $L_{\text {Aeq,24h }}$ sound levels is that it will not only be able to overcome the limitations of tonality and character of sound, but also be applicable to road, rail and aircraft noise. Thus ambient standards shall be applicable for various defined areas, including those prone to aircraft noise. The proposed standards are recommended for various areas categorized under silence, residential, commercial, industrial and mixed type zones and all type of noise sources ${ }^{13}$. A WHO report ${ }^{19}$ recommends that noise limits could be relatively high but rigidly enforced, or have a very low value with no legal binding whatsoever. Thus, the ambient standards proposed in the present context recommends reasonable values of ambient noise standards for various areas or zones (Table 1), so as to strictly enforce them for reducing noise pollution in the country ${ }^{13}$.

The legal sound insulation requirements are also another important aspect for controlling noise pollution as these are vital to fight against higher ambient noise levels. In view of acoustic comfort, there has been considerable research, particularly in Europe, for better sound insulation criteria to regulate the airborne and impact sound insulation between dwellings and airborne sound insulation of facades. Also, meeting the legal requirements does not guarantee sufficient acoustic comfort. Hence several countries in Europe have adopted classification schemes for better acoustic comfort which are further higher criteria than the legal requirements intended to provide the acoustic comfort. Presently, the National Building Codes of India recommend the sound insulation

Table 1. Proposed ambient noise standards ${ }^{13}$

\begin{tabular}{lll}
\hline Area code & Category of area/zone & $L_{\mathrm{Aeq}, 24 \mathrm{~h}}(\mathrm{~dB}(\mathrm{~A}))^{*}$ \\
\hline A & Industrial area & 70 \\
B & Commercial area, mixed zone & 65 \\
C & Residential area** & 60 \\
D & Silence zone** & 55 \\
\hline
\end{tabular}

*The modified adjustment factors to ISO 1996-1:2003 enlisted in Garg et al. ${ }^{13}$ should be applied to the measured $L_{\text {Aeq, } 24 \mathrm{~h}}$ in analysis of environmental noise.

**An additional $5 \mathrm{~dB}(\mathrm{~A})$ relaxation to the existing urban residential area with high population density and existing areas under silence zone may be provided by the competent authority depending upon the situation when there are only few alternatives left for application of noise abatement measures. criteria in terms of weighted sound reduction index $\left(R_{\mathrm{w}}\right)$ and minimum sound reduction $\left(D_{\mathrm{w}}\right)$ between rooms ${ }^{12}$.

However, in the light of many studies conducted in Europe $^{20,21}$ and wide usage of spectrum adaptation terms $\left(C, C_{\text {tr }}\right)$ the National Building Codes have to be amended utilizing the weighted standardized field-level difference, $D_{\mathrm{nT}, \mathrm{w}}$ as the descriptor used for in situ measurement of sound insulation. Table 2 shows the proposed criteria ${ }^{14}$ and descriptors for building elements based on the exhaustive literature survey. Class $\mathrm{C}$ refers to the minimum criteria that must be followed as chosen in other countries, while Class B is defined for the acoustic comfort having an average noise level reduction of the order of $35 \mathrm{~dB}$. Class A represents the high acoustic comfort levels achieved through a noise level reduction of $40 \mathrm{~dB}$. The $R_{\mathrm{w}}+C_{\mathrm{tr}, 50-3150} \geq 50 \mathrm{~dB}$ criterion is chosen for acoustic comfort criteria, when the outdoor noise level is within $70-75 \mathrm{~dB}(\mathrm{~A})$. The criterion is enhanced by $5 \mathrm{~dB}$ (Class A) for an outdoor noise level more than $75 \mathrm{~dB}(\mathrm{~A})$. The minimum criterion of weighted sound reduction index, $R_{\mathrm{w}}$ of $50 \mathrm{~dB}$ is judiciously chosen for new buildings for protection against external noise. The detailed explanation and basis of choosing these values can be found in Garg et $a l .{ }^{14}$. The choice between the sound insulation criterion down to $50 \mathrm{~Hz}$ or the common lower limit of $100 \mathrm{~Hz}$ may be exercised ${ }^{22}$ depending upon the calibration and measurement capabilities (CMCs) of testing laboratories engaged in sound transmission loss testing in India ${ }^{23,24}$. Thus, in the Indian context, clear-cut guidelines for sound regulation requirements like those in European member states shall not only provide a harmonization of sound descriptors with those followed in other countries, but shall also be helpful in reducing the R\&D costs for the building industry in India for development of suitable products or systems with desired noise level reductions ${ }^{25}$.

The technological advancement in building sciences adapting for light-weight, dry-wall construction materials with high strength and rigidity and improved sound insulation characteristics has to be thus brought in persistent use in Indian dwellings, rather than relying on massive constructions $^{26-28}$. It is envisaged that stricter building codes with respect to sound insulation requirements of building elements shall be implemented and strictly enforced in National Building Codes of India for new residential projects and 'smart cities' developed in the future to provide acoustic comfort to residents from the outside noise.

\section{Noise pollution control policies and measures}

The major objectives of a noise control programme should be to identify areas having high ambient noise levels in each part of the city, and evaluating the efficacy and suitability of noise abatement measures for bringing 


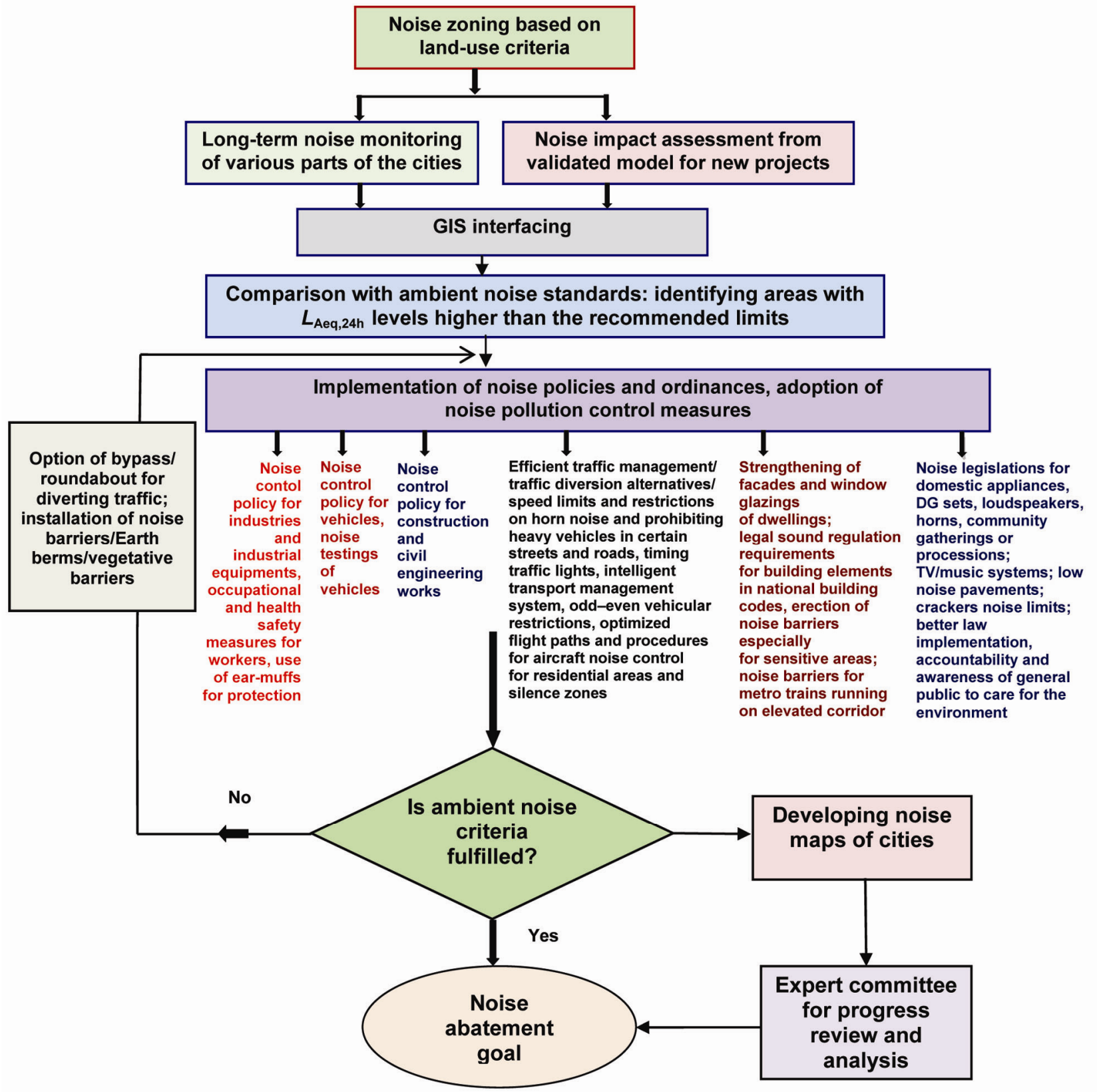

Figure 2. Flow chart of a noise pollution control strategy for reducing ambient noise levels in Indian cities.

these levels below the ambient noise standards. An appropriate noise policy suitable for controlling the noise exposure of various sources is necessary. Figure 2 shows a comprehensive and modified flow chart of a noise pollution control strategy for reducing the ambient noise levels in Indian cities, as discussed previously ${ }^{13}$. Noise zoning based on land-use criteria, noise monitoring and noise impact assessment using a validated model and implementation of policies and ordinances for noise control are the various aspects of the noise control programme to be emphasized. Noise mapping of the cities and ascertaining the compliance of ambient noise standards should be the major objective of such a programme. Adoption of a noise abatement goal as proposed in a Dutch study ${ }^{29}$ shall provide a roadmap for execution of such a programme at a diversified scale. However, special fundings, support from local municipal authorities, State Pollution Control Boards, transport and development authority such as Delhi Development Authority, as well as awareness among the general are needed for the accomplishment of $\operatorname{targets}^{30}$. For instance, a noise abatement goal may be formulated as follows: decreasing the number of houses exposed to a noise level $>75 \mathrm{~dB}(\mathrm{~A})$ by $100 \%,>70 \mathrm{~dB}(\mathrm{~A})$ by $90 \%$ and $>65 \mathrm{~dB}(\mathrm{~A})$ by $50 \%$ to be realized till 2030 . 
Table 2. Proposed criteria and descriptors for building elements ${ }^{14}$

\begin{tabular}{|c|c|c|c|c|}
\hline \multirow{2}{*}{$\begin{array}{l}\text { Building elements } \\
\text { Facades }\end{array}$} & \multicolumn{2}{|r|}{ Prescriptive criteria $(\mathrm{dB})$} & \multicolumn{2}{|r|}{ Verification criteria (dB) } \\
\hline & Class A & $R_{\mathrm{w}}+C_{\mathrm{tr}, 50-3150} \geq 55$ when $L_{\mathrm{d}}>75 \mathrm{~dB}(\mathrm{~A})$ & Class A & $D_{\mathrm{nT}, \mathrm{w}}+C_{\mathrm{tr}, 50-3150} \geq 50$ when $L_{\mathrm{d}}>75 \mathrm{~dB}(\mathrm{~A})$ \\
\hline & Class B & $R_{\mathrm{w}}+C_{\mathrm{tr}, 50-3150} \geq 50$ when $70 \leq L_{\mathrm{d}} \leq 75 \mathrm{~dB}(\mathrm{~A})$ & Class B & $D_{\mathrm{nT}, \mathrm{w}}+C_{\mathrm{tr}, 50-3150} \geq 45$ when $70 \leq L_{\mathrm{d}} \leq 75 \mathrm{~dB}(\mathrm{~A})$ \\
\hline & Class C & $R_{\mathrm{W}} \geq 50$ & Class C & $D_{\mathrm{nT}, \mathrm{w}} \geq 45$ \\
\hline & Class D & $R_{\mathrm{w}} \geq 45$ & Class D & $D_{\mathrm{nT}, \mathrm{w}} \geq 40$ \\
\hline \multirow[t]{3}{*}{ Between dwellings } & Class A & $R_{\mathrm{w}}+C_{50-3150} \geq 60$ & Class A & $D_{\mathrm{nT}, \mathrm{w}}+C_{50-3150} \geq 55$ \\
\hline & Class B & $R_{\mathrm{W}}+C_{50-3150} \geq 55$ & Class B & $D_{\mathrm{nT}, \mathrm{w}}+C_{50-3150} \geq 50$ \\
\hline & Class D & $R_{\mathrm{w}} \geq 47$ & Class D & $D_{\mathrm{nT}, \mathrm{w}} \geq 42$ \\
\hline Rooms in dwelling units & & $R_{\mathrm{w}} \geq 40$ & & $D_{\mathrm{nT}, \mathrm{w}} \geq 35$ \\
\hline $\begin{array}{l}\text { Classrooms, offices, kitchen } \\
\text { and utility rooms }\end{array}$ & & $R_{\mathrm{w}} \geq 45$ & & $D_{\mathrm{nT}, \mathrm{w}} \geq 40$ \\
\hline \multirow[t]{3}{*}{ Windows* } & Class A & $R_{\mathrm{w}}+C_{\mathrm{tr}, 50-3150} \geq 35$ & Class A & $D_{\mathrm{nT}, \mathrm{w}}+C_{\mathrm{tr}, 50-3150} \geq 30$ \\
\hline & Class B & $R_{\mathrm{w}}+C_{\mathrm{tr}, 50-3150} \geq 30$ & Class B & $D_{\mathrm{nT}, \mathrm{w}}+C_{\mathrm{tr}, 50-3150} \geq 25$ \\
\hline & Class C & $R_{\mathrm{w}} \geq 30$ & Class C & $D_{\mathrm{nT}, \mathrm{w}} \geq 25$ \\
\hline \multirow{3}{*}{ Doors* } & Class B & $R_{\mathrm{w}}+C_{\mathrm{tr}, 50-3150} \geq 25$ & Class B & $D_{\mathrm{nT}, \mathrm{w}}+C_{\mathrm{tr}, 50-3150} \geq 20$ \\
\hline & Class C & $R_{\mathrm{w}} \geq 25$ & Class C & $D_{\mathrm{nT}, \mathrm{w}} \geq 20$ \\
\hline & Class D & $R_{\mathrm{w}} \geq 20$ & Class D & $D_{\mathrm{nT}, \mathrm{w}} \geq 15$ \\
\hline
\end{tabular}

*If the size of windows and doors is more than $25 \%$ of the total area of the facade, the criterion for each class is further enhanced by $5 \mathrm{~dB}$. Choice between the sound insulation criterion down to $50 \mathrm{~Hz}$, or the common lower limit of $100 \mathrm{~Hz}^{\text {may be exercised }}{ }^{22}$.

Development of noise maps, setting up of expert committee for progress review and analysis like the National Committee for Noise Pollution Control (NCNPC), and targeting a noise abatement goal shall be key steps for controlling the noise pollution levels in the country.

The legal provisions for controlling noise pollution in India are: Indian Penal Code (section 268, 290, 291); Criminal Procedure Code (section 133); Factories Act, 1948; Motor Vehicles Act, 1988; Law of Torts; Air (Prevention and Control of Pollution) Act, 1981 and Environment (Protection) Act, 1986. Under Air (Prevention and Control of Pollution) Act, 1981, noise has been included in the definition of air pollutant ${ }^{31,32}$. The following control measures are suggested for noise emitted by various sources.

\section{Transportation noise control}

Transportation noise due to rail, road and aircraft should be specifically dealt with respect to the ambient noise standard proposed. The noise legislations for motor vehicles at the manufacturing stage are essential for controlling transportation noise. The noise limits for vehicles recommended by $\mathrm{CPCB}$ as applicable at manufacturing stage from 1 April 2005 should be effectively exercised ${ }^{33}$. Noise regulations should also be planned for future electric and hybrid vehicles. Enforcement of the proposed ambient standards shown in Table 1 valid for all the transportation sources shall be a large step for controlling noise pollution. The 'odd-even restrictions on vehicles' as executed in January and April 2016 in Delhi city can be also a good step for controlling vehicular traffic and noise levels provided that the public transport system is capable of catering to the daily transport needs of the public. Installation of noise barriers for the metro trains running on elevated corridors shall also be helpful in controlling the noise induced due to wheel-rail interaction, especially for dwellings located in the immediate vicinity. The abatement of aircraft noise particularly for the residents living near airports is also to be considered by adopting the noise reduction at source itself, optimized flights paths and procedures such as continuous descent approach, land-use planning and operating instructions for low noise emissions from the aircrafts, especially for the residential areas and silence zones.

\section{Motor vehicle horn noise}

Horns should be used only as traffic warning devices. A maximum level, $L_{\max }$ of $100 \mathrm{~dB}(\mathrm{~A})$ for noise made up of a single non-varying loudness is recommended. Experimental studies conducted at various sites in Delhi city have revealed that for areas with traffic noise having dominant horn noise component, octaves in the frequency range $2.5-4 \mathrm{kHz}$ are dominant ${ }^{34}$. Thus, for the abatement of traffic noise with a dominant horn noise component, sound insulation in octaves of $2.5-4 \mathrm{kHz}$ should be higher. However, the coincidence dip observed in sound transmission loss characteristics has to be controlled in this frequency range.

A back pane thickness of $10 \mathrm{~mm}$ is recommended to be used in a double glazing with an average air gap of $50 \mathrm{~mm}$ for controlling the coincidence dip. A $7 \mathrm{~mm}$ laminated glazing (PVB $0.76 \mathrm{~mm}$ ) in front and $10 \mathrm{~mm}$ at the 
back with an air gap of $50 \mathrm{~mm}$ has $R_{\mathrm{w}}+C_{\mathrm{tr}}$ value of $40 \mathrm{~dB}$ analytically predicted from Insul software ${ }^{35}$, and registers a coincidence dip at $1.6 \mathrm{kHz}$ (mass-air-mass resonance at $63 \mathrm{~Hz}$ ); it is quite effective for such applications. Garg et al. ${ }^{36}$ described the analytical formulations that can be readily used by manufacturers and architects to predict sound transmission loss in terms of singlenumber rating and selection of suitable glazing ${ }^{34,37,38}$ for achieving the desired noise-level reductions and reducing the honking noise.

\section{Fire-cracker noise}

The manufacture, sale or use of fire-crackers generating noise levels exceeding $125 \mathrm{~dB}(\mathrm{AI})$ or $145 \mathrm{~dB}(\mathrm{C})$ pk at $4 \mathrm{~m}$ distance from the point of bursting shall be prohibited. For individual fire-crackers constituting a series, the above-mentioned limit may be reduced by $5 \log 10(N) \mathrm{dB}$, where $N$ is the number of crackers joined together ${ }^{6}$. The noise from different brands of fire-crackers is tested every year at CSIR-National Physical Laboratory, New Delhi so as to ascertain whether the noise criteria are met or not.

\section{Loudspeaker noise and noise from community processions}

The noise level at the boundary of a public place, where a loudspeaker or public address system or any other noise source is being used shall not exceed $10 \mathrm{~dB}(\mathrm{~A})$ above the ambient noise standards for the area or $75 \mathrm{~dB}(\mathrm{~A})$, whichever is lower ${ }^{6}$. The peripheral noise level of privately owned sound system shall not exceed by more than $5 \mathrm{~dB}(\mathrm{~A})$ the ambient air quality standard specified for the area in which it is used, at the boundary of a private place. Night-timing restrictions should be imposed on air shows, public demonstrations, etc. In some cases, wherever appropriate, fines may also be imposed.

\section{Industrial noise}

The areas under industrial zone should follow the ambient noise standards recommended for such zones, as described in Table 1. The major noise sources in industrial units, including heavy machinery, power transformers, etc. should be enclosed, if possible, so as to reduce the exposure of workers high noise levels. Exposure to noise in an occupation environmental is recommended to be eight-hour continuous A-weighted sound pressure level, $L_{\text {Aeq,8h }}$ less than $85 \mathrm{~dB}(\mathrm{~A})$. For peak noise, the limit of Cweighted peak sound pressure level, $L_{\mathrm{C} \text {,peak }}$ of $140 \mathrm{~dB}(\mathrm{C})$ is proposed ${ }^{39}$. Isolating the receiver positions from noisy sources by increasing the distance between them and use of source enclosures, control rooms and screen can be helpful in the control of direct field. The reverberant field can be controlled by applying sound absorptive materials to room surfaces ${ }^{40}$. Apart from the implementation of occupational and health safety measures, ear muffs should be provided to workers and other staff in the industry for protecting them against long-term noise exposure.

\section{Diesel genset noise}

MoEF notifies that the sale of a product model not having valid type-approval certificate, or not complying with the noise limits as determined by the verification for Conformity of Production (COP), shall be prohibited in India. The noise limit imposed for generator sets run with kerosene or petrol is $86 \mathrm{~dB}(\mathrm{~A})$ sound power level ${ }^{41}$. The maximum permissible sound pressure level for new diesel generator (DG) sets with rated capacity up to $1000 \mathrm{KVA}$, manufactured on or after the 1 January 2005 is recommended as $75 \mathrm{~dB}(\mathrm{~A})$ at $1 \mathrm{~m}$ from the enclosure surface ${ }^{42}$. Noise from the DG set shall be controlled by providing an acoustic enclosure or by treating the room acoustically, at the users end. The acoustic enclosure or acoustic treatment of the room shall be designed for minimum $25 \mathrm{~dB}(\mathrm{~A})$ insertion loss or for meeting the ambient noise standards, whichever is on the higher side. The DG set shall be provided with proper exhaust muffler with insertion loss of minimum $25 \mathrm{~dB}(\mathrm{~A})$. Six laboratories in India have been authorized by MoEF for carrying out typeapproval and COP certification all over the country.

\section{Construction equipment noise}

Construction equipment operating in close proximity to residential areas can be of disturbance to the community. Thus, construction noise and vibration limits are essential, particularly those related to digging and piling operations for underground metro stations, etc. Table 3 shows the proposed noise limits for general construction at residential receptors ${ }^{43}$. The piling and digging operations not only cause vibrations which may induce cracks in building, but also produce airborne sound through building

Table 3. Proposed noise limits for commercial activities at residential receptors $^{43}$

\begin{tabular}{|c|c|c|c|}
\hline \multirow[b]{3}{*}{ Time period } & \multicolumn{3}{|c|}{$\begin{array}{l}\text { General construction activities } \\
L_{\mathrm{Aeq}, 15 \min }(\mathrm{dB}(\mathrm{A}))\end{array}$} \\
\hline & \multicolumn{3}{|c|}{ Duration of activity } \\
\hline & $\begin{array}{l}\text { Short } \\
\text { term }\end{array}$ & $\begin{array}{l}\text { Medium } \\
\text { term }\end{array}$ & $\begin{array}{l}\text { Long } \\
\text { term }\end{array}$ \\
\hline Daytime & 65 & 60 & 55 \\
\hline Evening period (6-10 p.m.) & 60 & 55 & 50 \\
\hline Late night (10 p.m-6 a.m.) & 45 & 45 & 45 \\
\hline
\end{tabular}


Policy stages

\begin{tabular}{|c|c|}
\hline $\begin{array}{c}\text { Agenda formulation } \\
\text { (noise problem identification) }\end{array}$ & Noise zoning based on land use criteria. \\
\hline \\
\hline $\begin{array}{c}\text { Problem analysis } \\
\text { (noise impact assessment) }\end{array}$ & $\begin{array}{l}\text { Long-term and short-term noise monitoring in various parts of a } \\
\text { city-preferred random monthly strategy; noise impact assessment } \\
\text { for new projects using a validated model. }\end{array}$ \\
\hline \multirow[b]{2}{*}{\begin{tabular}{c}
\multicolumn{1}{c}{$+\frac{}{\text { Policy formulation/adoption }}$} \\
(formulate ambient noise \\
regulations and ordinances) \\
\end{tabular}} & \multirow[b]{2}{*}{$\begin{array}{l}\text { Proposed ambient noise criteria, noise ordinances for loudspeakers, } \\
\text { DG sets, household appliances, vehicles, vehicular horns, construc- } \\
\text { tion equipments and activities, legal sound regulation requirements } \\
\text { in national building codes, noise awareness campaigns. }\end{array}$} \\
\hline & \\
\hline $\begin{array}{l}\text { Problem solution } \\
\text { (identification of noise control } \\
\text { measures, cost versus benefit } \\
\text { comparison, selection of BPEO) }\end{array}$ & $\begin{array}{l}\text { Setting up of an expert committee for reviewing various noise } \\
\text { pollution control measures like barriers, vegetation, earth berms, } \\
\text { low-noise pavements, efficient traffic management, strengthening } \\
\text { facades and windows, banning horns, reducing vehicular speed, } \\
\text { type approval noise testing of vehicles, option of bypass/highway/ } \\
\text { roundabout for traffic management. }\end{array}$ \\
\hline $\begin{array}{c}\text { Implementation } \\
\text { (execution of noise control } \\
\text { measures) }\end{array}$ & $\begin{array}{l}\text { Financial resources allocation, approvals from municipal or } \\
\text { development authorities; execution of best practicable and } \\
\text { economical option. }\end{array}$ \\
\hline \multicolumn{2}{|r|}{ ( } \\
\hline $\begin{array}{c}\text { Evaluation/progress review } \\
\text { (evaluation of noise control } \\
\text { measures) }\end{array}$ & $\begin{array}{l}\text { Ensuring ambient noise legislations are fulfilled, development of } \\
\text { noise maps of cities, noise annoyance surveys, development of expo- } \\
\text { sure-effect relationship, Noise Grievances Cell in each district. }\end{array}$ \\
\hline$\downarrow$ & \multirow{2}{*}{$\begin{array}{l}\text { Decreasing the number of houses exposed to a noise level, } L_{\text {Aeq, } 24 \mathrm{~h}} \\
>75 \mathrm{~dB}(\mathrm{~A}) \text { by } 100 \%,>70 \mathrm{~dB}(\mathrm{~A}) \text { by } 90 \% \text { and }>65 \mathrm{~dB}(\mathrm{~A}) \text { by } 50 \% \\
\text { by year } 2030 .\end{array}$} \\
\hline $\begin{array}{l}\text { Setting noise abatement } \\
\text { goal by year } 2030\end{array}$ & \\
\hline
\end{tabular}

Figure 3. Proposed framework for community noise assessment and abatement in India.

Table 4. Proposed noise limits for domestic appliances and construction equipment at manufacturing stage

\begin{tabular}{lc}
\hline Domestic appliance & $\begin{array}{c}\text { Maximum permitted } \\
\text { sound power level (dB(A)) }\end{array}$ \\
\hline Refrigerator and freezer & 55 \\
Washing machine, spin dry & 72 \\
Microwave oven & 70 \\
Electrical fan (desk fan, stand fan, wall fan, & 70 \\
$\quad$ ceiling fan) & 70 \\
Vacuum cleaner and dryer & 55 \\
Indoor heater & 72 \\
Air conditioners (split, indoor) & 72 \\
Air coolers & 75 \\
Hair dryer & 86 \\
Portable gensets (petrol or kerosene) & 90 \\
Food processor & 100 \\
Food blender & 110 \\
Lawn movers, welding generators, compressors & 120 \\
Handheld concrete breakers & \\
\hline
\end{tabular}

elements, which can be of annoyance to the residents. The noise labelling of construction equipment should be made mandatory as there are sometimes practical compli- cations involved in enforcement of standard noise limits for construction equipments especially in residential areas.

\section{Noise from domestic appliances}

Noise control in home appliances has to be economic, simple and easily implemented as there exists a global competition among manufacturers. An overall reduction of radiated noise levels of 6 and $10 \mathrm{~dB}$ have been reported in the domestic dryer and vacuum cleaner respectively, using the developed jute felt acoustical blanket ${ }^{44}$. Sound labelling of appliances shall be a helpful tool for creating awareness amongst manufacturers and customers about increasing the product quality by reducing noise emitted from the domestic appliances ${ }^{45}$. The noise limits should preferably be considered in terms of sound power level $^{46}$, which is constant for a given source and is independent of the acoustic environment. Sound power measurements $L_{\mathrm{WA}}$ are measured according to ISO 3744 (ref. 47) and ISO 3746 (ref. 48). Table 4 shows the proposed noise limits for domestic appliances and construction equipment at the manufacturing stage. 

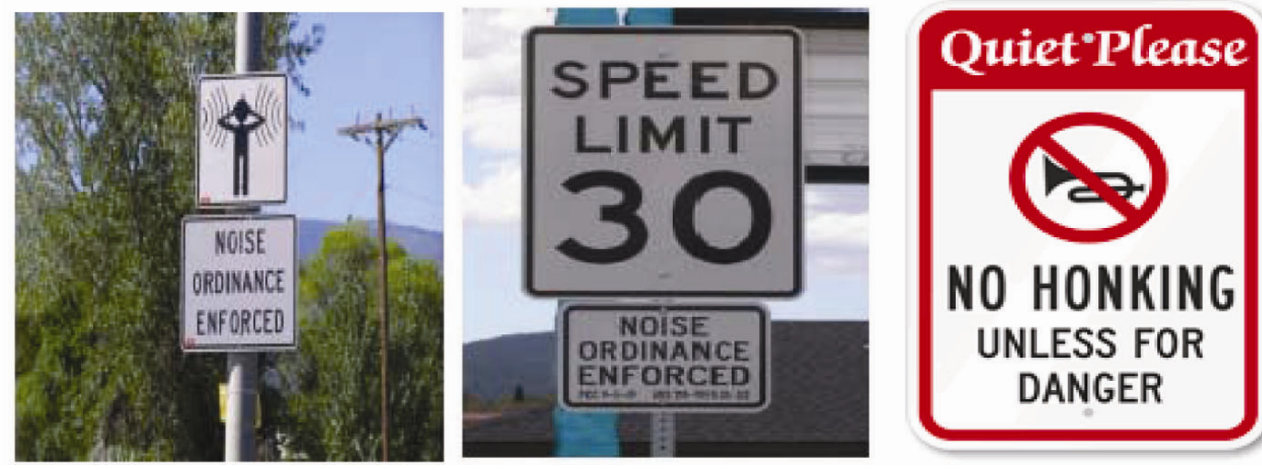

Figure 4. Illustrative noise ordinance signs for public awareness towards noise pollution $\operatorname{control}^{52,53}$.

Thus, the noise standards for all the sources in conjunction with the enforcement of the proposed ambient noise standards and legal sound insulation requirements shall be a vital step in fighting the noise pollution in India. Figure 3 assimilates all the measures, policies and discusses a proposed framework for community noise assessment and abatement in India as suggested in some studies $^{49-51}$. Illustrative noise ordinances sign (Figure 4), as suggested by Chanaud ${ }^{52}$, can be an effective step for educating about the existence and enforcement of noise ordinances, especially for heavy traffic density areas ${ }^{53}$. Proper measures should be undertaken to avoid long-term noise exposure to school children susceptible to higher noise levels during the mass-drill events, etc. Traffic policeman should be provided with ear-muffs so as to avoid hearing loss due to their prolonged exposure to long-term traffic noise. It is envisaged that awareness among general public in maintaining a 'noise-free community' is a must. Participation of NGOs and social websites $^{54}$ in creating awareness and educating people about noise and associated health hazards apart from school and college curriculum shall be a great step in this regard. The noise grievances cell as a part of State Pollution Control Boards should be proactive in receiving, analysing and taking appropriate action on complaints. Such complaints are more particularly on festival days as reported by Mandal and Bandyopadhyay ${ }^{55}$. Establishment of these noise grievance cells in each district and helpline number for easy accessibility and freedom to file a complaint can be a proactive step in this regard. Educative and innovative programmes such as organizing 'Noise Awareness Campaigns', 'Dhwani Pradushan Niyantran Diwas' (noise pollution control day) and integrating 'Noise Pollution Control Mission' as a part of the ongoing 'Swatch Bharat Mission' introduced by the Government of India shall be indispensable in controlling noise pollution in India. Socio-acoustic surveys, noise impact assessment studies due to various noise sources, and noise monitoring during festival days should be conducted in parallel to quantify the noise impact and assessment of induced noise annoyance ${ }^{56-60}$.

\section{Conclusion and recommendations}

A retrospective view of noise policies and ordinances in India and proposes revisions in them for noise abatement and control based on the available knowledge on noise policies and regulations followed in other countries is provided here. The work focused on inclusion of noise limits for construction activities, and domestic appliances apart from revision in ambient noise standards and $\mathrm{Na}$ tional Building Codes for enhancing the sound insulation of building elements for protection against noise pollution. The noise limits for domestic appliances, motor vehicles and construction equipment at the manufacturing stage and enforcement of ambient noise standards shall be helpful in controlling noise pollution in India.

The implementation of noise pollution control measures essentially requires a strategic noise abatement planning with enforcement of proposed ambient standards, revision in National Building Codes, exercising control limits on all the noisy sources and formulation of noise abatement goal. The suggested flow chart for reducing the ambient noise levels and targeting a noise abatement goal shall be a vital step in this regard for environmental protection in future. Identification of noisy hot spots having higher $L_{\mathrm{Aeq}, 24 \mathrm{~h}}$ sound levels than the recommended limits and implementing suitable noise abatement measures shall be indispensable for noise pollution control. Provision for the erection of noise barriers, especially for sensitive areas like hospitals, schools, colleges, old-age homes, religious institutions, etc. and other areas lying in the silence zone should be made in future projects planned. Studies on socio-acoustic surveys with an objective of correlating the noise annoyance with exposure, effect of noise levels on the human body and hearing loss, on workers in industry, effect of noise exposure on traffic policeman and workers at construction sites, etc. should also be conducted in parallel for increasing awareness of society towards controlling noise pollution levels in the country. It is envisaged that the proposed standards, revision in National Building Codes and noise control measures shall be indispensable in the development 
of 'smart cities' concept proposed by the Government of India.

1. World Health Organization (WHO), Burden of disease from environmental noise, Quantification by healthy life years lost in Europe, WHO Regional Office for Europe, Denmark, 2011.

2. Vijay, R., Sharma, A., Chakrabarti, T. and Gupta, R., Assessment of honking impact on traffic noise in urban traffic environment of Nagpur, India. J. Environ. Health Sci. Eng., 2015, 13(10), 1-9.

3. Banerjee, D., Research on road traffic noise and human health in India: review of literature from 1991 to current. Noise Health, 2012, 14, 113-118.

4. Martin, M. A., Tarrero, M. A., Gonzalez, A. and Macimbarrena, M., Exposure-effect relationships between road traffic noise annoyance and noise cost valuations in Valladolid, Spain. Appl. Acoust., 2006, 67(10), 945-958.

5. European Noise Directive, Assessment and Management of Environmental Noise, 2002/49/EU, Official Journal of European Communities, 2002.

6. Noise Pollution (Regulation and Control) Amendment rules, 2010; http://envfor.nic.in/legis/noise.htm

7. National Ambient Noise Monitoring Network, Information Brochure, Central Pollution Control Board, India, March 2011.

8. Central Pollution Control Board, Annual Report, 2011-12.

9. Garg, N. and Maji, S., A critical review of principal traffic noise models: strategies and implications. Environ. Impact Assess. Rev., 2014, 46, 68-81.

10. Garg, N., Mangal, S. K., Saini, P. K., Dhiman, P. and Maji, S., Comparison of ANN and analytical models in traffic noise modeling and predictions. Acoust. Aust., 2015, 43, 179-189.

11. Tachibana, H. and Lang, W. W., Final report of I-INCE TSG 3survey of legislation, regulations and guidelines for control of community noise, I-INCE Publication 09-1, July 2009.

12. National Building Codes of India: Part 8. Building Services: Section 4, Acoustics, Sound Insulation and Noise Control, Bureau of Indian Standards, CED 46 (0072) WD, 2015.

13. Garg, N., Kumar, A., Saini, P. K. and Maji, S., A retrospective view of ambient noise standards in India: status and proposed revision. Noise Control Eng. J., 2005, 63(3), 1-14.

14. Garg, N., Kumar, A. and Maji, S., Significance and implications of airborne sound insulation criteria in building elements for traffic noise abatement. Appl. Acoust., 2013, 74, 1429-1435.

15. Central Pollution Control Board, Ambient air quality and noise levels during Deepawali, 2013. Air Laboratory Report, 2013.

16. Garg, N., Saxena, T. K. and Maji, S., Long-term versus short-term noise monitoring: Strategies and implications in India. Noise Control Eng. J., 2015, 63(1), 26-35.

17. Garg, N., Sinha, A. K., Gandhi, V., Bhardwaj, R. M. and Akolkar, A. B., A pilot study on the establishment of national ambient noise monitoring network across the major cities of India. Appl. Acoust., 2016, 103, 20-29.

18. ISO 1996-1:2003, Acoustics - description, measurement and assessment of environmental noise - Part 1: Basic quantities and assessment procedures, International Organization for Standardization, Geneva.

19. WHO, Night Noise Guidelines for Europe, Copenhagen, Denmark: The World Health Organization Regional Office for Europe, 2009.

20. Rasmussen, B. and Rindel, J. H., Sound insulation between dwellings - descriptors applied in building regulations in Europe. Appl. Acoust., 2010, 71, 171-180.

21. Scholl, W., Lang, J. and Wittstock, V., Rating of sound insulation at present and in future. The Revision of ISO 717. Acta Acust. United Acust., 2011, 97, 686-698.

22. Rasmussen, B., International proposal for an acoustic classification scheme for dwellings-background and perspectives. In Proceedings Internoise, Melbourne, Australia, 2014.
23. Garg, N., Kumar, A. and Maji, S., Measurement uncertainty in airborne sound insulation and single-number quantities: strategy \& implementation in Indian scenario. MAPAN-J. Metrol. Soc. India, 2016, 31, 43-55.

24. Garg, N. and Maji, S., On analyzing the correlations and implications of single-number quantities for rating airborne sound insulation in frequency range $50 \mathrm{~Hz}$ to $5 \mathrm{kHz}$. Build. Acoust., 2015, 22(1), 29-44.

25. Helimäki, H. and Rasmussen, B., Airborne sound insulation descriptors in the Nordic building regulations - overview special rules and benefits of changing descriptor. In Proceedings of Baltic-Nordic Acoustics Meeting (BNAM), Bergen, Norway, 1012 May 2010, pp. 1-6.

26. Garg, N., Sharma, O. and Maji, S., Design considerations of building elements for traffic and aircraft noise abatement. Indian $J$. Pure Appl. Phys., 2011, 49, 437-450.

27. Garg, N., Kumar, A. and Maji, S., Parametric sensitivity analysis of factors affecting the sound insulation of multi-layered building elements. Arch. Acoust., 2014, 39(2), 165-176.

28. Rasmussen, B. and Machimbarrena, M., COST Action TU0901 Building Acoustics throughout Europe. Volume 1: Towards a Common Framework in Building Acoustic throughout Europe, 2014; http://www.costtu0901.eu/tu0901-e-books

29. Nijland, R., Vos, E. and Hooghwerff, J., The Dutch Noise Innovation Program Road Traffic (IPG). In Proceedings Internoise 2003, Seogwipo, Korea, 2003; http://www.informex.info/IPG_Internoise 203 ppr.pdf

30. Garg, N., Sharma, O., Mohanan, V. and Maji, S., Passive noise control measures for traffic noise abatement in Delhi, India. J. Sci. Ind. Res., 2012, 71, 226-234.

31. Singal, S. P., Noise Pollution and Control Strategy, Narosa Publishing House Pvt Ltd, 2005, pp. 170-203.

32. Yadav, P. and Yadav, R. S., Noise pollution and its enacting laws in India. G-J. Environ. Sci. Technol., 2013, 1(2), 51-56.

33. ENVIS Centre on Control of Pollution, Water, Air and Noise, Noise limits for vehicles at manufacturing stage; http://cpcbenvis.nic.in/noisepollution/Noise-vehicle.pdf

34. Garg, N., Investigations on modeling transportation noise and passive noise control measures for its abatement. Ph D dissertation, Delhi Technological University, 2016.

35. Insul software, Auckland, New Zealand; http://www.insul.co.nz

36. Garg, N., Kumar, A. and Maji, S., Parametric sensitivity analysis of factors affecting sound insulation of double glazing using Taguchi method. Appl. Acoust., 2013, 74, 1406-1413.

37. Garg, N., Sharma, O. and Maji, S., Experimental investigations on sound insulation through single, double and triple window glazing for traffic noise abatement. J. Sci. Ind. Res., 2011, 78, 471-478.

38. Garg, N., Sharma, O. and Maji, S., Design consideration for enhancing sound insulation characteristics of window glazing for traffic noise abatement. Build. Acoust., 2012, 19(2), 89-98.

39. National Standard for Occupational Noise, NOHSC:1007, National Occupational Health and Safety Commission, Australia, July 2000

40. Beranek, L. L. and Vér, I. L., Noise and Vibration Control Engineering: Principles and Applications, John Wiley, 1992.

41. CPCB, Noise limit for generator run with petrol/kerosene; http://cpcb.nic.in/noise_pollution/NoiseLimit4Genetator-SetsRunwithPetrol.pdf.

42. СPCB, Noise limit for generator sets run with diesel; http:// cpcb.nic.in/divisionsofheadoffice/pci2/noiselimit_diesegenset.pdf

43. Roberts, C., Construction noise and vibration impact on sensitive premises. In Proceedings of Acoustics, Australia, 23-25 November 2009.

44. Fatima, S. and Mohanty, A. R., Noise control of home appliancesthe green way. Noise Vibra. Worldwide, 2012, 26-34.

45. Maluski, S., Churchill, C. and Cox, T. J., Sound quality testing and labeling of domestic appliances in the UK. In Proceedings 
Internoise, Prague, Czech Republic, 22-25 August 2004; http://www.salford.ac.uk/ data/assets/pdf-file/0003/392736/maluski-Internoise-2004.pdf

46. Tian, J., Jiao, F. and Lu, Y., The latest development of low noise household appliances in China. In Proceedings International Institute of Noise Control Engineering, Paris, 5-6 July 2011.

47. ISO 3744:2010, Acoustics - Determination of sound power levels and sound energy levels of noise sources using sound pressure Engineering methods for an essentially free field over a reflecting plane, International Organization for Standardization, Geneva.

48. ISO 3746:2010, Acoustics - Determination of sound power levels and sound energy levels of noise sources using sound pressure Survey method using an enveloping measurement surface over a reflecting plane, International Organization for Standardization, Geneva.

49. Hede, A., Environmental noise regulation: a public policy perspective. In Noise as a Public Health Problem (Noise Effects '98), (eds Carter, N. L. and Job, R. F. S.), Sydney, Australia, 1998, vol. 2, pp. 687-696.

50. Schwela, D., Finegold, L. S. and Stewart, J., A strategic approach on environmental noise management in developing countries. In 9th International Congress on Noise as a Public Health Problem, Foxwoods, CT, USA, 2008

51. WHO, Guidelines for community noise, World Health Organization, Geneva, 2000.

52. Chanaud, R. C., Noise ordinances, tools for enactment, modification and enforcement of a community noise ordinance, 2014; https://www.noisefree.org/Noise-Ordinance-Manual.pdf

53. Road traffic signs; http://www.roadtrafficsigns.com/truck-sign/ quite-please-no-honking-unless-for-danger-sign/sku-k-6179.aspx

54. http://awaaz.org/Awaaz Foundation/Noise Press Coverage/Noise $\underline{\text { Press Coverage.html }}$
55. Mandal, P. K. and Bandyopadhyay, A., Case study from West Bengal, India: management of noise levels during festival time in Kolkata and Howrah Municipal Corporation areas from 2002 to 2011. Environ. Qual. Manage., 2014, 23(3), 13-32.

56. Banerjee, D., Road traffic noise exposure and annoyance: a crosssectional study among adult Indian population. Noise Health, 2013, 15(66), 342-346.

57. Garg, N., Sharma, O. and Maji, S, Noise impact assessment of mass rapid transit systems in Delhi city. Indian J. Pure Appl. Phys., 2011, 49, 257-262.

58. Upadhyay, J. K. and Jain, V. K., Aircraft-induced noise levels in some residential areas of Delhi. Environ. Monit. Assess., 1999, 56, 195-207.

59. Jamir, L., Nongkyrnuh, B. and Gupta, S. K., Community noise pollution in urban India: need for public heath action. Indian $J$. Community Med., 2014, 39, 8-12.

60. Garg, N., Vishesh and Maji, S., Fuzzy TOPSIS approach in selection of optimal noise barrier for traffic noise abatement. Ach. Acoust., 2015, 40, 453-467.

ACKNOWLEDGEMENTS. We thank the CPCB officials especially A. K. Sinha and R. M. Bhardwaj for sharing their experiences and data in NANMN project. We also thank the Director, CSIR-National Physical Laboratory, New Delhi and the Head, Apex Level Standards and Industrial Metrology Division for their support and providing infrastructural facilities for the study. The views and opinions expressed in this article are those of authors and do not necessarily reflect the official policy or position of any agency of the Government of India.

Received 10 July 2015; revised accepted 29 February 2016

doi: $10.18520 / \mathrm{cs} / \mathrm{v} 111 / \mathrm{i} 1 / 29-38$ 